\title{
FAKTOR-FAKTOR YANG MEMPENGARUHI KECENDERUNGAN PAHAM TEOLOGI \\ Oleh
}

Prof.Dr. M. Basir Syam, M.Ag.

\begin{abstract}
Abstrak
Karya ilmiah ini adalah suatu studi tentang perkembangan pemahaman teologi Islam. Perkembangan tersebut mengalami perubahan yang bersifat fluktuatif dari paham tradisional ke paham rasional. Perubahan tersebut dipengaruhi oleh faktorfaktor pendidikan. Dalam tulisan ini juga dikemukakan beberapa variabel yang diprediksi berpengaruh terhadap kecenderungan pemahaman teologi seseorang, yakni variabel: umur, jenis kelamin, etnis, organisasi sosial, tingkat pendidikan, jenis pendidikan, intensitas penerimaan informasi aktual dan kegiatan ilmiah. Penulis berasumsi bahwa tingkat pendidikan, jenis pendidikan, intensitas penerimaan informasi aktual dan kegiatan ilmiah secara signifikan dapat mempengaruhi kecenderungan paham teologi. Adapun umur, jenis kelamin, etnis dan organisasi sosial hanya bersifat random. Tulisan ini diharapkan menjadi motivasi untuk melakukan survei di lapangan.
\end{abstract}

Keyword:

Teologi Islam, Teologi Tradisional, Teologi Rasional, Paham teologi dan faktorfaktor yang berpengaruh.

\section{Perubahan dari Paham Tradisional ke Rasional}

Pada masa awal perkembangan Islam, studi Islam lebih cenderung bersifat tekstual, yakni berdasarkan Al Quran dan hadis. Para sahabat Nabi menerima ajaran Islam sesuai dengan apa yang disampaikan oleh Nabi. Kecenderungan seperti ini juga umumnya diikuti oleh para tabi'in. Mereka menahan diri dalam memberikan interpretasi rasional terhadap kedua sumber tersebut, yang menyimpang dari kaidah bahasa. Para ulama yang mendominasi studi Islam pada masa itu dikenal sebagai salafal-shälih.

Sejak penampilan Islam di dunia internasional yang dimulai dengan takluknya daerah-daerah: Syam, Syiria, Mesir dan Persia, para ulama dalam menyampaikan dakwahnya berhadapan dengan pemeluk agama lain yang ada di negeri itu. Mereka itu tidak serta merta bersedia menerima Islam, bahkan banyak diantaranya yang menolaknya dengan menggunakan argumentasi rasional. Tidak mengherankan kalau dunia Islam menjadi ajang perdebatan akibat kritikan dan polemik yang dilancarkan oleh mereka.

Di antara ulama ada yang meneliti jalan pikiran dan argumentasi mereka, kemudian menelaah cara berpikir rasional dan menggunakannya sebagai senjata apologi dalam menghadapi tantangan yang ada. Hal itu tampak jelas pada ulama kalam, khususnya di kalangan Mu'tazilah. Mereka merintis penggunaan argumentasi rasional dalam studi Islam, dan kemudian cara berpikir itu menyentuh keseluruhan aspek pendidikan Islam.

Studi Islam yang bercorak rasional tersebut terutama mengalami kemajuan pesat pada masa pemerintahan Abbasiyah. Selain karena inisiatif para khalifah, 
juga peranan ulama, khususnya dari kalangan Mu'tazilah tidak dapat dilupakan, karena merekalah yang banyak memberikan dukungan moril. Seperti telah dijelaskan sebelumnya, dakwah mereka yang banyak ditujukan kepada para pemeluk agama lain pada daerah-daerah yang baru ditaklukkan dinilai cukup berhasil dengan menggunakan argumentasi rasional. Pola pemikiran teologi mereka yang rasional itu sangat relevan dengan upaya pembangunan yang digalakkan oleh penguasa Abbasiyah. Oleh karena itu, tidak mengherankan jika aliran teologi ini banyak dianut oleh kalangan pejabat negara pada masa itu.

Mu'tazilah yang telah berjasa membela Islam dari serangan luar dengan argumen-argumen rasionalnya, setelah menjadi aliran resmi negara pada masa kepemimpinan al-Ma'mun (872 M) mengindoktrinasikan ajaran- ajarannya kepada seluruh lapisan umat Islam. Salah satu hal yang menjadi fitnah dan membawa kekacauan adalah pendapat mereka tentang Al Quran sebagai makhluk (baharu). Hal ini dijadikan sebagai ujian untuk mengukur kepatuhan orang-orang Islam dalam menganut ajaran Mu'tazilah. Pemaksaan ini menimbulkan reaksi dari kalangan ulama hadis (Ahl al-Sunnah) seperti Imam Ahmad ibn Hambal. Keadaan tersebut berlangsung terus dalam tiga masa kekuasaan Bani Abbasiyah, yakni alMa'mün, al-Mu'tashim dan al-Wätsiq (813-847 M). Selama masa itu banyak ulama hadis (Ahl al-Sunnat) yang korban. ${ }^{1}$

Ketegangan yang terjadi akibat kekerasan dan pemaksaan ajaran Al Qur'an sebagai makhluk itu dapat diredam dengan tampilnya al-Mutawakkil sebagai khalifah Abbasiyah. Khalifah ini kemudian mencabut kedudukan Mu'tazilah sebagai satu-satunya aliran resmi negara $(848 \mathrm{M}) .^{2}$ Dengan demikian, kebebasan menganut aliran kembali ditegakkan. Dalam suasana kemunduran Mu'tazilah, muncullah dua orang tokoh intelektual yang berkecenderungan membela paham.Ahl al-Sunnah, Abu al-Hasan Ali ibn Ismail al-Asy'ari (873-935 M) yang sebelumnya adalah seorang pengikut yang taat dari Mu'tazilah dan bermazhab fiqih Syafi'i, menyerang Mu'tazilah di Bashrah (pusat), sedangkan Abu Manshur al-Maturidi yang bermazhab Hanafi menghadapi Mu'tazilah di Samarkand (daerah cabang). Kedua tokoh inilah dan para pengikut masing-masing yang berhasil mencampakkan Mu'tazilah dari kehidupan umat. ${ }^{3}$

Setelah jatuhnya Mu'tazilah, pengkajian yang bercorak rasional di bidang teologi Islam, mengalami kemandekan. Selanjutnya, aliran Ahl al- Sunnah khususnya. Asy'ariah mengalami perkembangan pesat dan merambah dunia Islam terutama pada abad ke-11 sampai abad ke-13. Perkembangan tersebut terutama didukung oleh Nizham al-Mulk, seorang wazir Bani Saljuk; yang mempunyai komitmen berpegang teguh pada doktrin Asy'ariah di bidang teologi dan Syafiiyyah di bidang fiqih. ${ }^{4}$

${ }^{1}$ Muhammad Ibn Abdul Karim al-Bazdawi, Kitab Ushuluddin, Kairo: Isa al-Babi alHalabi wa Syurakaih, hlm. 51. Lihat pula P.Sj. Van Koningsveld. "Naskah Yunani tentang bait al hikmah dan kebijaksanaan beragama khalifah al Ma'mun." dalam Herman Leonard(Ed), Studi Belanda Kontemporer tentang Islam (Jakarta: INIS, 1993), hlm.69

${ }^{2}$ Lihat "Teologi Islam", Op.Cit., hlm. 63

3 Lihat S.Amer Ali, The Spirit of Islam, Terjemahan H.B, Yasin "Api Islam" (Jakarta:Bulan Bintang, 1979) hlm. 646. Teologi Islam, Op.Cit.,hlm.

${ }^{4}$ Lihat Azymardi Azra, Jaringan Ulama Timur Tengah dan Kepulauan Nusantara Abad XVII dan XVIII (Bandung: Mizan, 1995) hlm. 62 
Nizhäm al-Mulk mulai mendirikan madrasah Ahl al-Sunnah. di Baghdad pada tahun 1067 M. Kemudian madrasah yang terkenal dengan Nizhâmiyyah itu dikembangkan pula di berbagai kota-kota Islam seperti Basrah, Mosul (Irak), Isfahan, Nisyafur, Merv, Balkh, dan Herat (Iran). Penguasa-penguasa Muslim lainnya di Timur Tengah juga mengikuti langkah Nizam al-Mulk tersebut. Madrasah-madrasah ini selain berfungsi sebagai transfer ilmu pengetahuan juga terutama mencetak ulama-ulama Ahl al-Sunnah. Di antara ulama Asy'ariah yang muncul dari perguruan tersebut adalah Imam al-Haramain dan al-Ghazâli. ${ }^{5}$

Pada dasarnya pola pemahaman teologi yang dianut oleh umat Islam hingga abad ke-19 M. masih tergolong Ahl al-Sunnath, kecuali di Iran, yang secara resmi menganut mazhab Syi'ah. Oleh beberapa penulis seperti Ja'far SubhanI, Murtadha Mutahhari dan Ali Shari'ati ditunjukkan bahwa negeri tersebut terakhir ini, di antara warganya yang menganut Syi'ah juga mempunyai pandangan teologi yang bercorak rasional ala Mu'tazilah. ${ }^{6}$

Adanya gerakan pemurnian yang dilakukan oleh kelompok Salafiyah, yang dipelopori oleh Ibn Taimiyah pada abad ke-14 M, meskipun banyak mengkritik pemikiran Asy'ariah, pandangan mereka tentang takdir dan perbuatan manusia tidak jauh berbeda dengan pandangan Ahl al-Sunnah pada umumnya. Ibn Taimiyah sendiri, bahkan mengkritik dengan tegas penggunaan argumentasi filosofis dalam studi Islam khususnya teologi dan menerima secara tekstual semua ayat-ayat yang bersifat musayyar (jabar), meskipun beliau menegaskan bahwa takdir hanya dapat diimani dan tidak pantas dijadikan hujjah, khususnya ketika terjerumus pada perbuatan buruk. ${ }^{7}$

Perlu dikemukakan di sini bahwa bangkitnya pemikiran teologi rasional pada zaman modern, dimulai pada abad ke $19 \mathrm{M}$, setelah terjadi kontak antara pemikiran Barat dan pemikiran Islam khususnya di Mesir. Para intelektual Muslim seperti al-Tahtawi, Jamaluddin al-Afghani, Muhammad Abduh dan Rasyid Ridha, mulai menyadari keterbelakangan yang menimpa dunia Islam dan mencoba menganalisis sebab-sebab kemundurannya. Mereka menggarisbawahi bahwa salah satu penyebab kemunduran itu adalah faktor teologis yaitu paham dinamika dan kemerdekaan manusia telah hilang dari kaum Muslimin dan yang tinggal adalah paham fatalisme yang menyelubungi pola pikir mereka.

Di Indonesia, kesadaran akan perlunya pembaharuan pemikiran Islam dimulai sejak awal abad ke-20 M., yang ditandai dengan munculnya gerakan pembaharuan di bidang sosial dan pendidikan. Pembaharuan tersebut dimotori antara lain oleh organisasi sosial seperti Syarekat Islam, Muhammadiyah, Nahdlatul Ulama dan sebagainya. Organisasi yang tersebut terakhir ini, meskipun tetap menghargai tradisi yang ada sebelumnya, secara perlahan-lahan beradaptasi dengan perkembangan modern yang telah tumbuh dan berkembang di dunia Islam pada umumnya.

\footnotetext{
${ }^{5}$ Ibid, hlm. 63

${ }^{6}$ Lihat Murthada Mutahari, al-Adl al-Ilahi. Terjemahan Agus Efendi dengan judul "Keadilan Ilahi" (Bandung: Mizan, 1992) hlm.28. lihat Ja'far Subhani., al-Qadha wa al-Qadar fi al-Ilmi wa al- Falsafah,Teheran: Dar al Tabligh al-Islami,h.54.

${ }^{7}$ Lihat Syaikh al Islam Ibn. Taimiyah, al-Qada wa al Qadar wa-al ihtijad bi al qadar, terjemahan Ahmad Faiz Asifuddin "Qadha Qadar” (Jakarta: Pustaka Mantiq, 1996), hlm.23-24
} 
Setelah Indonesia merdeka, kesempatan Muslim Indonesia melakukan kontak dengan masyarakat Muslim di Dunia Internasional semakin terbuka, sehingga perkembangan baru dalam pemikiran Islam pun semakin banyak yang dapat diketahui. Hal yang tidak kalah pentingnya adalah bahwa orang- orang Indonesia yang melakukan studi di negara Barat pun semakin banyak dan mereka dapat mengambil segi-segi positif dari ilmu pengetahuan dan pemikiran modern pada umumnya.

Pada akhir abad ke-20 M ini pendidikan Islam di Indonesia semakin terbuka menerima metode ilmu pengetahuan dalam mengembangkan studi- studi keislaman, sehingga cara berpikir rasional dan objektif semakin banyak mendapatkan perhatian. Suatu hal yang sangat menunjang berkembangnya cara berpikir rasional dan objektif itu adalah sarana informasi dari media massa, seperti pers, radio, televisi dan internet yang semakin mudah dijangkau oleh seluruh lapisan masyarakat. Dalam era globalisasi seperti sekarang ini, sangat mungkin terjadi pergeseran nilai budaya, sekurang-kurangnya dalam bentuk adaptasi terhadap nilai budaya yang lebih positif.

Dewasa ini di Indonesia belum tampak seberapa jauh paham teologi rasional menjadi anutan masyarakat Islam, oleh karena penelitian mengenai hal ini masih sangat langka dilakukan oleh para peneliti. Akan tetapi dapat diduga bahwa orang-orang Islam yang telah menerima kehadiran ilmu pengetahuan modern sebagai suatu hal yang dapat dipertemukan dengan nilai- nilai kebenaran yang terkandung dalam ajaran Islam adalah mereka yang mendukung teologi yang bercorak rasional, yakni paham teologi yang menekankan kebebasan manusia.

Hamka misalnya, menurut Abdul Aziz Dahlan, berpendapat bahwa konsep takdir yang mestinya dikembangkan adalah paham yang mampu menumbuhkan keberanian serta menunjang ikhtiar manusia, sementara paham takdir yang menyebabkan kelesuan dan mengarah ke paham Jabariyah hendaknya dikikis ${ }^{8}$ M. Yunan Yusuf dalam disertasinya mengungkapkan bahwa pemikiran teologi Hamka yang tertuang dalam Tafsir al-Azhar banyak persamaannya dengan pandangan teologi Mu'tazilah. Dalam kesimpulan disertasi itu diungkapkan bahwa enam di antara delapam masalah teologi yang dianalisis yakni:free will dan predestination, konsep iman, kekuasaan dan kehendak mutlak Tuhan, dan sifat-sifat Tuhan sejalan dengan pandangan Mu'tazilah. Adapun dua masalah lainnya, yakni kekuatan akal dan fungsi wahyu lebih dekat pada pandangan Maturidiyah Bukhara. ${ }^{9}$

Pandangan yang lebih tegas menghendaki perlunya pembaharuan di bidang teologi dikemukakan oleh Harun Nasution. Menurut pendapatnya, bahwa maju mundurnya peradaban Islam sangat erat kaitannya dengan pandangan teologi yang dianut umat Islam. Dalam kuliah-kuliah beliau di Pascasarjana IAIN Syarif Hidayatullah seringkali dikemukakan bahwa kemajuan umat Islam pada abad pertengahan adalah karena ditunjang oleh paham teologi, terutama pandangan rasional Mu'tazilah yang menekankan kebebasan manusia dan menjadikan

\footnotetext{
${ }^{8}$ Lihat Abd. Azis Dahlan, Pemikiran Muhammadiyah dalam bidang Teologi Islam (Jakarta: IAIN Syarif Hidayatullah, 1983) hlm. 18-20

${ }^{9}$ Lihat. M. Yunan Yusuf, Corak Pemikiran Kalam Tafsir Al Azhar (Jakarta: Pustaka Panji Mas 1990) hlm. 172
} 
sunnatullah sebagai acuan dalam pandangan keilmuan mereka. Demikian pula sebaliknya bahwa kemunduran umat Islam erat kaitannya dengan tersebarnya paham kehendak mutlak Tuhan di dunia Islam setelah tersingkirnya pengaruh aliran rasional tersebut. Oleh karena itu, menurut Harun Nasution, jika umat Islam mendambakan kemajuan, mesti menegakkan kembali sistem teologi rasional tersebut. $^{10}$

Demikianlah sekelumit tinjauan historis tentang hubungan antara corak perkembangan pendidikan Islam dan aliran teologi. Dalam era globalisasi informasi sekarang ini perkembangan ilmu pengetahuan dan teknologi tidak hanya menyentuh pemikiran orang-orang terpelajar, melainkan juga disaksikan oleh masyarakat umum melalui media massa: pers, radio, televisi dan internet, sehingga pandangan teologi umat Islam dimungkinkan beradaptasi ke arah yang lebih rasional.

\section{Faktor-Faktor Yang Berpengaruh Terhadap Kecenderungan Aliran Teologi Islam}

Pada uraian ini dikemukakan beberapa teori tentang faktor-faktor yang dianggap relevan dengan pola pemahaman teologi. Diangkatnya faktor-faktor ini sebagai variabel bebas mengingat kenyataan sejarah bahwa perkembangan pola pemahaman teologi tertentu pada suatu masa erat kaitannya dengan corak pendidikan yang dominan pada masa itu.

Corak pendidikan dewasa ini yang lebih berorientasi pada ilmu pengetahuan dan teknologi modern juga telah mewarnai cara berpikir umat Islam di Indonesia. Untuk mengetahui pengaruh tersebut dapat ditelusuri melalui beberapa faktor-faktor pendidikan berikut ini.

1. Faktor Umur.

Dilihat dari perspektif ini, manusia mengalami perkembangan psikis, sesuai dengan tahapan-tahapan umur yang dilaluinya. Ch. Buhler membagi tahapan perkembangan umur manusia atas : 0 - 25 tahun, adalah masa permulaan dan penanjakan memasuki kehidupan dunia; 25 - 50 tahun adalah puncak masa hidup produktif; 50 tahun ke atas manusia mulai memasuki masa tua, yaitu masa dimana manusia mulai menarik diri dari aktivitas kehidupan. Masa terakhir ini ditandai dengan menurunnya fungsi-fungsi biologis secara drastis. ${ }^{11}$

Cuming dan Henri mengemukakan bahwa proses menjadi tua itu biasanya dibarengi dengan melepaskan diri dari dunia sekitarnya. Orang- orang yang memasuki masa tua biasanya lebih cenderung mengisolasi diri dari ikatan-ikatan sosial. Hal ini menurut kedua psikolog tersebut merupakan suatu hal yang wajar, karena dengan jalan demikian orang-orang tua dapat merasa lebih tenang dan bahagia $^{12}$

${ }^{10}$ Catatan Kuliah Sejarah Pemikiran Teologi Islam. Bandingkan dengan tujuh puluh tahun Harun Nasution (Jakarta: Lembaga Studi Agama dan Filsafat, 1989) hlm. 37

11 Lihat F.J. Monks, et.al., Fisikologi Perkembangan (Yogyakarta:UGM Press, 1984, hlm.7)

12 Ibid., hlm 271. Bandingkan dengan Andi Mappiare Fisikologi Orang Dewasa, (Surabaya: Usaha Nasional, 1983 hlm. 199) 
Selain pembagian umur (masa perkembangan) tersebut, sebagian ahli psikologi perkembangan membagi umur manusia atas: masa permulaan hingga remaja (0-21 tahun), masa dewasa dini (21 - 40 tahun), masa dewasa madya (40 60 tahun), dan masa tua (60 tahun ke atas). ${ }^{13}$

Berdasarkan teori tersebut di atas penulis berasumsi bahwa pada dasarnya orang-orang yang sudah memasuki masa tua, disebabkan karena kekuatan mereka sudah sangat menurun, maka sikap optimis (percaya diri) mereka pun mengalami kemunduran. Mereka lebih cenderung membebaskan diri dari berbagai tanggung jawab kehidupan. Sebaliknya, orang-orang yang baru memasuki masa dewasa dini justru lebih bersemangat dan optimis untuk menghadapi berbagai tanggung jawab kehidupan. Hal ini ditunjang oleh fisik mereka yang masih prima. Meskipun pada masa dewasa dini banyak mengalami konflik akibat hubungan sosial yang kurang harmonis yang dapat membawa akibat frustrasi.

Selanjutnya, orang-orang dewasa yang masih muda (dewasa dini) lebih percaya kemampuan dirinya dalam menghadapi segala tantangan atau problematika kehidupan dibanding dengan orang-orang yang sudah memasuki masa tua. Oleh karena itu, ada kemungkinan bahwa semakin tua seseorang semakin cenderung bersikap pasrah kepada Tuhan. Dengan demikian, mereka lebih cenderung menganut pola pemahaman teologi yang berdasarkan kehendak mutlak Tuhan.

Sebaliknya, jika umur manusia dikaitkan dengan tingkat pendidikan maka dapat terjadi bahwa semakin tua umur seseorang semakin banyak informasi dan ilmu pengetahuan yang dapat diserap. Semakin banyak informasi aktual dan ilmu pengetahuan yang diserap, maka semakin rasional pandangan mereka, sehingga ada kemungkinan mereka lebih cenderung menganut pola pemahaman teologi yang bercorak rasionalistik seperti Mu'tazilah.

2. Jenis Kelamin (Gender)

Apabila seseorang memperhatikan perbedaan fisik pria dan wanita maka didapatinya bahwa fisik pria lebih kuat dari pada wanita. Sebagian besar ahli fisiologi juga mengakui hal yang demikian. Menurut Save M. Dagun, adanya perbedaan kekuatan otot antara pria dan wanita antara lain disebabkan karena wanita mengalami siklus bulanan atau menstruasi, dalam hal ini perobahan sel-sel kimiawi yang bersifat drastis berpengaruh atas kekuatan fisiknya. Selain itu kaum pria mempunyai bentuk paru-paru lebih besar. Oleh karena itu, pria dapat menghirup oksigen yang lebih banyak, denyut jantungnya lebih kuat, aliran oksigen dalam darahnya lebih besar, hemoglobinnya yang membawa oksigen ke dalam otot lebih banyak dan itu menyebabkan kaum pria lebih stabil dalam stamina. $^{14}$

Akan tetapi, menurut sebagian ahli fisiologi perbedaan itu hanya karena faktor kebudayaan yaitu kebiasaan-kebiasaan selama ini memberikan pekeijaan yang berat bagi kaum pria dan sebaliknya pekerjaan yang halus untuk kaum wanita. Mereka optimis bahwa jika latihan-latihan yang diberikan kepada wanita sama dengan apa yang selama ini menjadi kebiasaan pria, maka wanitapun

${ }^{13}$ Lihat EB Hurlock Developmental Psychology, (New York:Mc. Grow - Hill Book Company, 1959) hlm. 64

${ }^{14}$ Save and Dagun, Maskulin dan Feminim (Jakarta:Rineka Cipta 1992) hlm 33. 
sanggup berbuat yang sama. Mereka mengemukakan beberapa kasus atlet wanita yang mampu mencapai prestasi dalam kompetisi olah raga. ${ }^{15}$

Andi Mappiare mengemukakan bahwa adanya fenomena perbedaan yang mencolok antara kekuatan kaum pria dan wanita disebabkan karena faktor kebudayaan tradisional yang selama ini menempatkan kaum pria sebagai kaum yang memiliki otoritas yang istimewa di atas kedudukan kaum wanita. Dalam kebudayaan modern perbedaan itu semakin tipis karena yang ditonjolkan adalah individualitas seseorang, apakah itu isteri atau suami, bahkan anak-anak juga diakui individualitasnya. Dengan demikian, memberi kesempatan kepada setiap pribadi untuk berkembang dan bersaing untuk meraih prestasi. ${ }^{16}$

Dari segi perbedaan psikologis, para psikolog juga tidak memiliki kesamaan pandangan mengenai adanya superioritas kaum pria atas kaum wanita. Sebagian mereka berpendapat bahwa kaum pria lebih banyak berorientasi rasional dalam memecahkan problematika yang dihadapinya, sementara kaum wanita lebih banyak dikuasai oleh perasaannya dari pada rasio (akal pikiran)-nya dalam menghadapi problematika kehidupannya ${ }^{17}$

Sebagian psikolog lainnya berpendapat bahwa pada dasarnya tidak ada perbedaan antara laki-laki dan perempuan dalam hal kecerdasan. Pada zaman modern ini gerakan emansipasi wanita telah membuktikan bahwa kaum wanita mampu melakukan kegiatan-kegiatan di berbagai bidang intelektual, karir dan kepemimpinan. Oleh karena itu, adanya kesenjangan antar kaum pria dan wanita dalam bidang-bidang tersebut hanya karena disebabkan oleh faktor-faktor kultural, dimana kesempatan yang diberikan pada kaum wanita sangat terbatas ${ }^{18}$

Dalam ajaran Islam, meskipun terdapat dalil al-Qur'an yang mengutamakan kaum pria dalam hal kepemimpinan, sebagian ulama menanggapi bahwa dalil tersebut bersifat kondusif, sehingga tidak tertutup kemungkinan bagi kaum wanita untuk tampil sebagai pemimpin dalam struktur sosial dan politik. ${ }^{19}$

Diangkatnya teori-teori tentang perbedaan fisik dan psikologis pria dan wanita adalah sebagai pendekatan untuk mengetahui tingkat optimis dan pesimis mereka dalam menghadapi problematika kehidupan. Perbedaan optimis dan pesimis seseorang erat kaitannya dengan kepercayaan pada kemampuan diri; hal itu melahirkan persepsi tentang kemungkinan adanya hubungan dengan kecenderungan pola pemahaman teologi tentang takdir dan perbuatan manusia.

3. Suku (Etnis)

Hubungan antara suku dan pola pemahaman teologi antara lain dapat dilihat dari segi stratifikasi sosial yang ada dalam suatu masyarakat. Masyarakat etnis yang hidup dengan perbedaan dan tingkatan sosial yang ketat lebih cenderung bersifat pasrah menerima nasib. Demikianlah hal itu dapat dilihat dalam masyarakat feodalistik, dimana kelompok masyarakat lapisan bawah lebih patuh mengabdi untuk kepentingan lapisan atas. Sebaliknya, dalam masyarakat modern

\footnotetext{
${ }^{15}$ Ibid, Hlm. 37

${ }^{16}$ Fisikologi Orang Dewasa, Op.Cit., hlm 46-47

17 Murthada Mutahhari, The Rights of Woman in Islam, diterjemahkan oleh Ummu Munayah dengan judul “ Hak-hak Wanita dalam Islam” (Jakarta: YAPI 1989, hlm. 108)

${ }^{18}$ Andi Mappiare, Op.Cit. Hlm 55

${ }^{19}$ Hasil dialog dengan Munawir Sjadzali dalam perkuliahan sistem politik dalam islam (Pada tanggal 23 September 1995)
} 
yang demokratis anggota masyarakatnya lebih merdeka dan kritis dalam menghadapi setiap permasalahan.

Keadaan seperti tersebut di atas, sejalan dengan apa yang dikemukakan oleh Nurcholis Madjid bahwa teologi Asy'ariah bersifat kompromistik dengan kebudayaan Jawa yang mengenal hierarki sosial sehingga dalam masyarakat Islam tradisional ini lahir strata sosial yang religio- feodalisme ${ }^{20}$

Jika teori tersebut dikaitkan dengan masyarakat Islam yang ada di Sulawesi Selatan pada masa awal masuknya Islam di daerah ini, memang cukup relevan, mengingat bahwa pada umurnya kebudayaan suku-suku yang ada pada waktu itu, khususnya Bugis-Makassar juga mengenal hierarki sosial seperti yang ada dalam masyarakat Jawa. Menurut H.J. Friedericy, sebelum masuknya Islam di Sulawesi Selatan sudah ada tiga lapisan masyarakat Bugis-Makassar, yakni : 1)Ana' karung (ana' karaeng dalam bahasa Makassar), yaitu lapisan kaum kerabat raja-raja; 2) Tomaradeka (Tu-maradeka dalam bahasa Makassar), yaitu lapisan orang merdeka yang merupakan bagian besar dari rakyat; dan 3) A ta, yaitu lapisan orang budak, orang yang ditangkap dalam peperangan, orang yang tidak dapat membayar hutang atau orang yang melanggar pantangan adat. Ia lebih lanjut menjelaskan bahwa lapisan ketiga (budak) sudah mulai hilang pada awal abad ke-20 karena larangan pemerintah kolonial dan atas desakan Islam. ${ }^{21}$

Menurut Mattulada, sesudah Perang Dunia II, perbedaan antara lapisan ana anung dan to-maradeka dalam kehidupan masyarakat juga sudah mulai menipis. Adapun gelar-gelar anak arung seperti Puang, Karaenta, Andi dan Daeng, meskipun masih dipakai, namun tidak lagi mempunyai makna seperti dahulu. Sekarang malahan sering dengan sengaja diperkecilkan artinya dalam proses perkembangan sosialisasi dan demokratisasi masyarakat Indonesia. ${ }^{22}$

4. Tingkat Pendidikan

Pelaksanaan tujuan pendidikan tentu saja tidak dapat dilakukan sekaligus, melainkan melalui tahapan-tahapan yang berlangsung sepanjang hidup manusia. Dalam pendidikan formal juga dijabarkan melalui tingkatan-tingkatan sekolah secara hierarki mulai dari taman kanak-kanak, SD, SLTP, SLTA, SOI - SI, S2 hingga S3.

Konsekuensinya, semakin tinggi tingkat pendidikan seseorang, semakin tinggi pula taraf ilmu pengetahuan yang diterima. Semakin tinggi taraf ilmu pengetahuan yang dimiliki, maka semakin luas wawasan pemikiran rasioanal yang dimiliki. Semakin rasional cara berfikir seseorang, maka memungkinkan seseorang cenderung menganut pola pemahaman teologi yang rasional.

Kemungkinan lain hanya dapat terjadi jika yang bersangkutan dibesarkan dalam lingkungan keluarga dan masyarakat yang menganut pola pemuliaan teologi tradisional atau lembaga pendidikan tempat menimba ilmu pengetahuan yang bersangkutan lebih cenderung menerapkan paham-paham teologi yang

20 Nurcholis Madjid “ Keimanan Pesantren, antara materi dan metodologi” dalam pesantren, perdana Oktober sampai Desember, 1984, hlm 15-16. Lihat Pula M. Mansyur Amin (Editor ) Teologi Pembangunan, Paradigma Baru Pemikiran Islam (Yogyakarta: LKPSM, NU, DIY, 1989), hlm.213

${ }^{21}$ Lihat Mattulada "Kebudayaan Bugis Makassar" dalam Koentjaraningrat, Manusia dan Kebudayaan di Indonesia (Jakarta: Djambatan, 1995) hlm.176

${ }^{22}$ Ibid 
berlandaskan kehendak mutlak Tuhan. Oleh karena itu, tidak mengherankan jika seorang doktor atau guru besar menganut pola pemahaman Ahl al-Sunnah bahkan Jabariyah.

5. Jenis Pendidikan

Jenis pendidikan ini dipilih sebagai salah satu faktor mengingat bahwa munculnya pandangan teologi rasional erat kaitannya dengan berkembangnya pengetahuan rasional dan empirik. Seperti telah dijelaskan bahwa tokoh-tokoh Mu'tazilah pada umumnya banyak menimba pengetahuan filsafat pada masanya. Demikian pula para modernis Islam yang muncul sejak abad ke-19 $\mathrm{M}$ hingga kini juga tidak bisa dilepaskan dari pengaruh perkembangan ilmu pengetahuan dan teknologi modern.

Konsekuensinya bahwa jenis pendidikan umum lebih banyak menerapkan metode berpikir rasional dan empirik dibanding dengan jenis pendidikan diniyah, meskipun jenis lembaga pendidikan yang tersebut terakhir ini tidak terlepas dari pengaruh tersebut. Berdasarkan hal tersebut, penulis berasumsi bahwa para alumni lembaga pendidikan umum lebih memungkinkan melakukan pendekatan rasional dalam memahami konsep-konsep keagamaan dibandingkan dengan alumni lembaga pendidikan keagamaan. Oleh karena itu, dalam memahami persoalanpersoalan teologis kemungkinan besar mereka lebih cenderung kepada pola pemahaman teologi Mu'tazilah dibanding mereka yang berlatar belakang pendidikan keagamaan.

Kemungkinan lain bisa terjadi jika pelajaran agama yang diterapkan pada lembaga pendidikan umum lebih banyak berdasarkan pola pemahaman tradisional yang menekankan kehendak mutlak Tuhan. Sementara pada lembaga pendidikan diniyah sudah diperkenalkan pola pemahaman teologi Mu'tazilah yang bercorak rasional, sehingga para lulusan lembaga pendidikan umum berkembang sikap ambivalen yakni pada sisi penalaran ilmiahnya menunjukkan sikap rasional dan objektif, sementara pada keyakinan keagamaannya sangat tradisional dan cenderung menekankan kehendak mutlak Tuhan. Sebaliknya, para lulusan lembaga pendidikan diniyah dapat lebih bersemangat untuk mengembangkan pemikiran rasional, khususnya di bidang teologi Islam. Oleh karena itu, tidak mengherankan jika terdapat banyak cendekiawan muslim yang berlatar belakang pendidikan diniyah menganut pola pemahaman teologi rasional dewasa ini.

6. Organisasi Sosial (Ormas) Islam

Organisasi Sosial Islam yang ada hingga kini, pada kenyataannya mempunyai peranan penting dalam proses pembangunan bangsa dan negara dan telah berjasa mengangkat harkat dan martabat umat Islam di Indonesia.

Nahdlatul Ulama, yang cikal bakalnya dimulai dengan ta'wir al- Afkar, sebuah forum diskusi yang dibentuk di Surabaya tahun 1914 oleh sekelompok ulama pesantren berhaluan Ahl al-Sunnah wa al-Jama'at antara lain K.H. Abdul Wahab Hasbullah. Kemudian secara resmi Jamiah Nahdlatul Ulama didirikan tahun 1926 oleh K.H. Hasyim Asyari bersama K.H. Abdul Wahab Hasbullah. Organisasi ini diperkuat dengan diterimanya gagasan yang disampaikan oleh Komite Hijaz kepada raja Arab Saudi untuk menghargai ajaran-ajaran mazhab empat dan faham Ahl al-Sunnah wa al-Jama' ${ }^{23} h^{23}$

${ }^{23}$ Lihat Slamet Effendi Yusuf Et al "Dinamika Kaum Santri Menelusuri Jejak dan 
Syarekat Islam yang didirikan di Solo tahun 1911 oleh Haji Samanhudi, pada mulanya bernama Syarekat Dagang Islam (SDI). Organisasi ini awalnya bergerak di bidang sosial ekonomi. Setelah namanya berubah menjadi Syarekat Islam, maka organisasi ini mulai berkiprah di bidang politik. Organisasi ini tidak menegaskan haluannya sebagaimana Nahdlatul Ulama dengan komitmen Ahl alSunnat, melainkan hanya menyebut Islam sebagai dasarnya. Organisasi ini berupaya mengangkat persatuan ummat lewat gerakan politik, dakwah, sosial, ekonomi dan pendidikan dengan mengesampingkan persoalan khilafiyah. ${ }^{24}$

Muhammadiyah didirikan pada tahun 1912 oleh K.H. Achmad Dahlan, tampaknya organisasi ini banyak mendapatkan inspirasi dari gerakan pemurnian Islam yang dilakukan oleh Muhammad ibn Abd al-Wahhab dan gagasan Muhammad Abduh untuk meninggalkan mazhab dan kembali kepada al-Qur'an dan Sunnah Nabi. ${ }^{25}$ Organisasi ini jelas tidak berhaluan pada suatu aliran teologi tertentu. Namun demikian, gerakan pembaharuannya sangat identik dengan gerakan Salafiyyah.

Himpunan Mahasiswa Islam (HMI) yang lahir pada tahun 1947, juga tidak berhaluan suatu paham teologi, kecuali berdasarkan Islam. Dalam anggaran dasarnya dikemukakan bahwa salah satu usaha organisasi ini adalah membina mahasiswa Islam untuk menuju terciptanya insan mu'abbid, mujahid, mujtahid dan mujaddid. Berdasarkan hal ini, HMI adalah salah satu organisasi sosial Islam yang berupaya melakukan pembaharuan pemikiran terutama di kalangan insan akademik. Pembaharuan tersebut meliputi aspek keagaman, kebudayaan, politik, pendidikan dan ekonomi ${ }^{26}$ Organisasi ini tampaknya paling banyak berkiprah dalam kepemimpinan orde baru bersama ABRI dibanding dengan anggota organisasi lainnya.

Semua organisasi tersebut di atas, tidak ada yang berhaluan aliran teologi tertentu selain Nahdlatul Ulama yang secara eksplisit memuat dalam anggaran dasarnya Oleh karena itu, penulis berasumsi bahwa meskipun sepanjang sejarah Islam di Indonesia, secara formal umat Islam menganut paham Ahl ahSunnah wa al Jama'ah, kecenderungan untuk menganut pola pemahaman teologi rasional dewasa ini sangat terbuka, khususnya dari kalangan masyarakat terpelajar. Hal ini ditunjang pula oleh gerakan pembaharuan yang pada umumnya diperjuangkan dan diterima baik oleh organisasi sosial Islam.

7. Informasi Aktual

Media massa merupakan alat komunikasi yang sangat efektif dalam menyampaikan pesan. Meskipun pesan yang disampaikan lewat media massa bermacam-macam, alat komunikasi tersebut tetap terikat dengan kode etik kebenaran. Keberadaan media massa dengan fungsinya sebagai penyebar informasi aktual berdasarkan fakta, dengan sendirinya berfungsi pula sebagai alat

Pergolakan Internal NU (Jakarta: Rajawali Press) hlm 9 dan 20

${ }^{24}$ Lihat Muhammad Abdul Ghani, Cita Dasar dan Pola Perjuangan Syarikat Islam (Jakarta: Bulan Bintang 1984) hlm 17,24, dan 201

${ }^{25}$ Lihat Yusuf Abdullah Fuard, Perjuangan dan Pengabdian Muhammadiyah (Jakarta: Pustaka Antara, 1989) hlm 1-3

${ }^{26}$ Lihat Agussalim Sitompul, HMI Dalam Pandangan Seorang Pendeta (Jakarta: Gunung Agung 1984) hlm. 12 
pencerdasan manusia. Konsekuensinya, semakin banyak seseorang membaca, semakin bertambah pula kecerdasan dan wawasan pemikiran rasionalnya

Seperti telah dijelaskan sebelumnya bahwa semakin rasional cara berpikir seorang muslim, maka kemungkinan untuk menganut pola pemahaman teologi rasional juga sangat besar meskipun kemungkinan lain bisa terjadi karena faktorfaktor tertentu. Munculnya para pembaharu pada abad ke-19 M. seperti Jamaluddin al-Afghani dan Syekh Muhammad Abduh, walaupun kedua tokoh ini menentang kehadiran kolonial di negeri-negeri Islam, informasi-iformasi Barat yang sangat sarat dengan pemikiran rasional dan faktual telah menjadi pendorong bagi keduanya untuk mengubah cara berpikir umat Islam pada masanya yang selama beberapa abad, menurut mereka telah diselubungi oleh kejumudan serta sikap fatalistik yang menyebabkan keterbelakangan.

Umat Islam dewasa ini, khususnya para da'i berhadapan dengan berbagai informasi aktual lewat media massa yang semakin canggih dan pada umumnya diwarnai dengan cara berpikir rasional dan objektif. Oleh karena itu, dalam merespon perkembangan modern, mereka akan mencari cara berpikir yang lebih sesuai dengan perkembangn zaman. Dalam hal ini, pola pemahaman teologi Mu'tazilah merupakan salah satu alternatif yang muncul dari akar sejarah pemikiran Islam.

8. Faktor Kegiatan Ilmiah

Kegiatan ilmiah, baik yang dilakukan dalam rangka kegiatan akademik maupun yang berlangsung di luar kampus, yang diselenggarakan oleh lembagalembaga sosial seperti seminar, simposium, dan berbagai diskusi ilmiah adalah sangat efektif dalam mentransfer ilmu pengetahuan. Dalam acara-acara seperti itu baik pembawa materi acara maupun para peserta sama-sama aktif dalam mendiskusikan masalah-masalah ilmiah tertentu. Oleh karena itu, waktunya yang relatif singkat, memacu perhatian untuk memahami apa yang dibahas dalam kegiatan tersebut.

Demikian pula kegiatan ilmiah lainnya, seperti menulis artikel, makalah dan karya ilmiah lainnya juga menggunakan konsentrasi yang maksimal dengan menerapkan metode-metode ilmiah yang dimiliki penulisnya. Diantara para pembaca yang juga memahami persoalan yang dibahas, jika memiliki sikap kritis, akan memberikan tanggapan terhadap kekurangan-kekurangan tulisan yang dibacanya berdasarkan prinsip-prinsip rasional dan objektif.

Orang-orang yang banyak terlibat mengambil bagian dalam kegiatan tersebut, secara faktual tentu memiliki wawasan pemikiran ilmiah yang luas. Oleh karena itu, penulis berasumsi bahwa mereka yang mempunyai pengalaman banyak dalam kegiatan ilmiah akan lebih cenderung menganut pola pemahaman teologi rasional. Kemungkinan sebaliknya dapat teijadi jika yang bersangkutan selama hidupnya hanya disuguhi dengan dakwah dan pendidikan dari paham teologi tradisional yang berdasarkan kehendak mutlak Tuhan.

\section{Kesimpulan}

1. Perkembangan pemahaman teologi mengalami fluktuasi. Perkembangan tersebut bergerak dari paham tradisional ke paham yang bersifat rasional. 
Pemahaman teologi selain berpijak pada sumber-sumber ajaran Islam juga dipengaruhi oleh faktor internal dan eksternal.

2. Penulis berasumsi bahwa faktor-faktor pendidikan berupa jenis pendidikan, tingkat pendidikan,intensitas informasi aktual dan kegiatan ilmiah akan mempengaruhi kecenderungan paham teologi. Sementata, umur, jenis kelamin, etnis dan organisasi sosial kemungkinan pengaruhnya hanya bersifat random. Untuk membuktikan asumsi ini perlu dilakukan riset lapangan. 